\title{
BARRIERS TO REPORTING PATIENT SAFETY INCIDENT IN HEALTH CARE WORKERS: INTEGRATIVE LITERATURE REVIEW
}

\author{
Hambatan Pelaporan Insiden Keselamatan Pasien Pada Tenaga Kesehatan: \\ Integrative Literature Review \\ *Deasy Amelia Nurdin ${ }^{1}$, Adik Wibowo ${ }^{1}$ \\ ${ }^{1}$ Administration and Health Policy Department, Faculty of Public Health, University of Indonesia, Indonesia \\ Correspondence $^{\star}$ : \\ Address: Gedung F, Lt.1, Kampus FKM UI, Depok, Indonesia | e-mail: deasyamel@yahoo.co.id
}

\begin{abstract}
Background: The patient safety incident reporting systems is designed to improve the health care by learning from mistakes to minimize the recurrence mistakes, however the reporting rate is low.

Aims: Integrative literature review was chosen to identify and analyze the barriers of reporting patient safety incidents by health care workers (HCWs) in hospital.

Methods: Searching for articles in electronic database consisting of Medline, CINAHL and Scopus resulted in 11 relevant articles originating from 9 countries.

Results: There are differences but similar in barriers to reporting patient safety incident among HCWs. The barriers that occur are the existence of shaming and blaming culture, lack of time to report, lack of knowledge of the reporting system, and lack of support from the management.

Conclusion: Each hospital has different barriers in reporting incident and the interventions carried out must be in accordance with the existing barriers.
\end{abstract}

Keywords: barrier of reporting, incident reporting, patient safety incident

\begin{abstract}
Abstrak
Latar Belakang: Sistem pelaporan insiden keselamatan pasien dibuat agar rumah sakit dapat mempelajari insiden yang terjadi sehingga meminimalisir terulangnya kesalahan yang sama, namun angka pelaporan dari tenaga kesehatan dirasa belum optimal.

Tujuan: Integrative literature review dipilih untuk mengidentifikasi dan menganalisis hambatan yang terjadi pada tenaga kesehatan dalam melaporkan insiden keselamatan pasien di rumah sakit.

Metode: Pencarian artikel dalam basis data elektronik yang terdiri dari Medline, CINAHL dan Scopus menghasilkan 11 artikel yang relefan dan berasal dari 9 negara.

Hasil: Hambatan dalam pelaporan insiden keselamatan pasien pada tenaga kesehatan memang beragam namun memiliki kemiripan. Hambatan yang terjadi ialah adanya budaya shaming dan blaming, kurangnya waktu untuk melapor, kurangnya pengetahuan tentang sistem pelaporan, dan kurangnya dukungan dari manajemen.

Kesimpulan: Setiap rumah sakit memiliki hambatan yang berbeda-beda dalam pelaporan insiden dan intervensi yang dilakukan harus sesuai dengan hambatannya.
\end{abstract}

Kata kunci: hambatan pelaporan, pelaporan insiden, insiden keselamatan pasien 


\section{Introduction}

In the world of health, anything that has the potential to cause injury to patients must be watched out by health care workers (HCWs). They must record and communicate the incidents that were seen and carried out. Incident reporting is included in the patient safety program because it is a learning system that will lead to improving patient safety and security for HCWs at hospital (World Health Organization, 2020).

Patient safety incident (PSI) reporting is one of the hospital indicators, but it is not done consistently even though HCWs are aware that there is a reporting system in their workplace. Errors in health services are the result of weaknesses in a work system. To produce the right solution, it is necessary to identify the root cause of the error. One way that can be done is to report patient safety incidents internally and externally because incident is a tool to detect problems related to patient safety in the hospital.

The patient safety incident reporting system is the monitoring and prevention of injury to patients. The purpose of the reporting system is to learn from mistakes so as to minimize the recurrence of the same mistakes (Samsiah et al., 2016) (M. Christopher, 2016) (Dhamanti, et al., 2020)

$\mathrm{HCW}$ s play an important role in PSI reporting, but the information is not fully understood. In Malaysia, the number of reported incidents is lower than the actual number of incidents. Medication errors were estimated to only around $28.9 \%-50 \%$. Research in Saudi Arabia demonstrated $79 \%$ of the incidents were unreported because HCWs had difficulties in reporting them (Samsiah et al., 2016).

Doctors tend to only report serious incidents when compares to nurses and pharmacists who also report near miss (Samsiah et al., 2016). In Iran, even though the reporting system has been made anonymously, around $45 \%$ of nurses are still reluctant to report it (Fathi et al., 2017). In Indonesia, a total of 1,227 hospitals have been accredited, but only 668 incidents were reported in 2016, whereas when compared to Taiwan, every year there are
50.000 incidents reported (Dhamanti, et al., 2020).

Hospital leaders need to show a positive attitude towards incident reporting because it leads to improving the quality and safety of patients in the hospital. The first step can be done by building awareness among HCWs of the importance of reporting and definition of incidents that need to be reported. The percentage of the reported number can be displayed to all $\mathrm{HCW}$ and used as an indicator of quality in the hospital (Fathi et al., 2017).

The three important stages in incident reporting are awareness and knowledge of the reporting system, the ability to recognize reported incidents, and the ability to handle incidents so they don't happen again (Dhamanti, et al., 2020). An integrative literature review was chosen to identify and analyse the barriers that occur in HCWs in reporting PSI in the hospital.

\section{Analysis and Discussion Literature Search}

The search for articles was sourced from electronic database journals consisting of Medline, CINAHL, and Scopus using Boolean techniques in keyword searches "Patient Safety Incident AND Reporting Barriers" with publication period of journal articles from 2016 to 2020 .

In the first stage of the search, there were 450 articles with 44 duplicates. The next stage after reading the title and abstract resulted in 37 articles. After adjusting to the inclusion criteria, the final results of the 11 articles were analysed in this study and stored in Mendeley to be read in full text. Table 1 illustrates the number of articles identified in each database. A peer review process of some articles took place to minimize bias. Issues found on the articles were then identified.

\section{Inclusion and Exclusion Criteria}

The inclusion criteria used were original research journal articles and reviews in English which could be accessed in the full text, the study population was $\mathrm{HCW}$ s and the results of the research were the barriers of reporting on PSI. 
Table 1. Search Strategy

\begin{tabular}{|c|c|c|c|}
\hline Base & Terms & $\begin{array}{l}\text { Number of } \\
\text { Publications }\end{array}$ & $\begin{array}{l}\text { Studies } \\
\text { Included }\end{array}$ \\
\hline Medline & $\begin{array}{l}\text { patient safety reporting barrier AND (fulltext:("1" OR "1") AND } \\
\text { db:("MEDLINE")) AND (year_cluster:[2016 TO 2020]) }\end{array}$ & 73 & 4 \\
\hline CINAHL & $\begin{array}{l}\text { Full Text; Published Date: 20160101-20201231; Abstract } \\
\text { Available; English Language; Exclude MEDLINE records; } \\
\text { Publication Type: Academic Journal; Document Type: Article }\end{array}$ & 258 & 2 \\
\hline Scopus & $\begin{array}{l}\text { ABS (patient AND safety AND reporting AND barrier) AND } \\
\text { ( LIMIT-TO (PUBSTAGE, "final" )) AND ( LIMIT- } \\
\text { TO (PUBYEAR, 2020) ) OR LIMIT- } \\
\text { TO (PUBYEAR, 2019) OR LIMIT- } \\
\text { TO (PUBYEAR, 2018) OR LIMIT- } \\
\text { TO (PUBYEAR, 2017) ) OR LIMIT- } \\
\text { TO (PUBYEAR, 2016 ) ) AND ( LIMIT- } \\
\text { TO (DOCTYPE, "ar" ) OR LIMIT-TO ( DOCTYPE, "re" ) ) }\end{array}$ & 117 & 4 \\
\hline
\end{tabular}

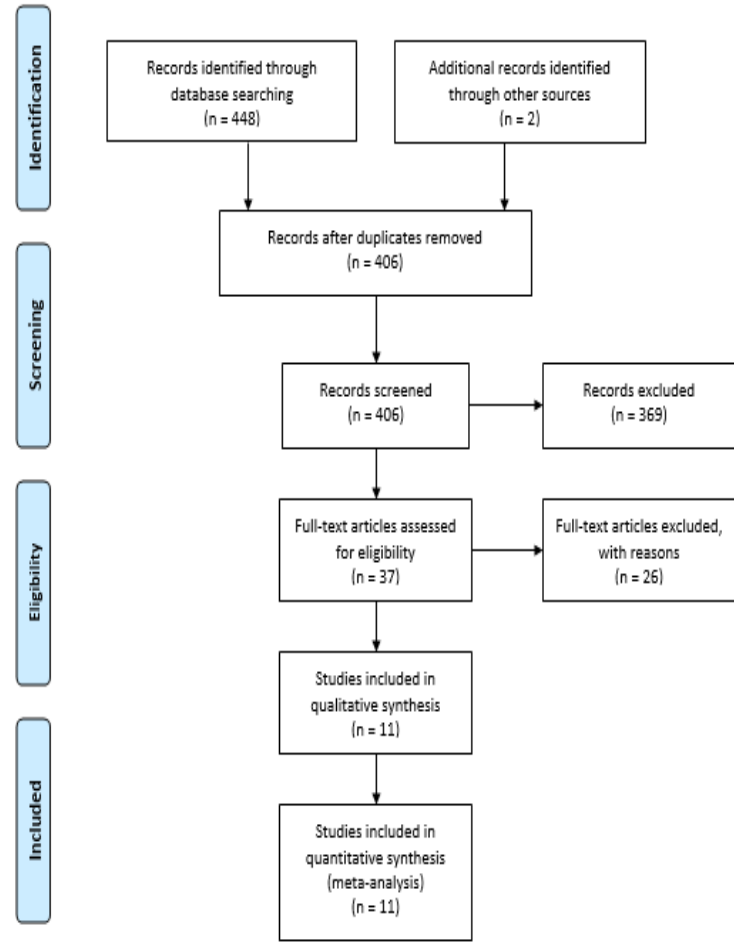

Figure 1. PRISMA flow diagram of search and selection process

\section{Data Extraction}

This integrative literature review uses a flowchart form Preferred Reporting Items for Systematic Review \& Meta-Analysis (PRISMA) so that article selection can be carried out more systematically as shown in Figure 1.

There were 11 articles that matched the inclusion criteria. The characteristics of the articles are depicted in Table 2. Among the 9 identified countries (UK, Norway,
Uganda, Brazil, Iran, Malaysia, Qatar, United States, and Indonesia), the barriers to reporting PSI in $\mathrm{HCW}$ s are similar to one and another.

In the Table2, the result of article extraction shows that the barriers by the majority of HCWs are shame and fear of being blamed when PSI occurs.

Other barriers are the lack of time to report due to high workload, did not understanding how the reporting system is, a work environment that does not support a reporting culture, not knowing what to report, and the perception that incident reporting is not their responsibility.

The barriers for HCWs in reporting PSI actually vary from one hospital to another. The strategy developed must be in accordance with the constraints so that will be more focus on the problem (Fathi et al., 2017).

To prevent errors in future care, the hospital must be aware of the problems that occur and act according to the result obtained from incident reporting (M. Christopher, 2016)

Incident reporting systems must be made in a good way (De Fatima et al., 2019). Because incident reporting and the result analysis are useful for increasing awareness of patient safety culture. Analysis is an important part of incident reporting because it determines the causes of incidents and prevents them from recurring (Rea \& Griffiths, 2016). 
Table 2. Characteristics of Studies

\begin{tabular}{|c|c|c|c|c|}
\hline Title & $\begin{array}{c}\text { Authors, } \\
\text { Year of } \\
\text { Publication, } \\
\text { Country }\end{array}$ & $\begin{array}{l}\text { Research } \\
\text { Methods }\end{array}$ & $\begin{array}{l}\text { Research } \\
\text { Sample }\end{array}$ & $\begin{array}{c}\text { Barriers in PSI } \\
\text { Reporting }\end{array}$ \\
\hline $\begin{array}{l}\text { Barriers to Reporting } \\
\text { of Adverse Drugs } \\
\text { Reactions: } \\
\text { a Cross Sectional } \\
\text { Study among } \\
\text { Community } \\
\text { Pharmacists } \\
\text { in United Kingdom }\end{array}$ & $\begin{array}{l}\text { (Cheema et } \\
\text { al., 2017), } \\
\text { UK }\end{array}$ & $\begin{array}{l}\text { Cross-sectional } \\
\text { design with } \\
\text { online and } \\
\text { offline } \\
\text { questionnaires }\end{array}$ & 138 pharmacists & $\begin{array}{l}\text { Lack of time } \\
\text { ( } 46.4 \%), \\
\text { perceived } \\
\text { serious } \\
\text { incidents to be } \\
\text { reported } \\
(65.2 \%) \text {, and no } \\
\text { need for } \\
\text { reporting } \\
(37.0 \%)\end{array}$ \\
\hline $\begin{array}{l}\text { Medication Errors } \\
\text { and Safety Culture } \\
\text { in a Norwegian } \\
\text { Hospital }\end{array}$ & $\begin{array}{l}\text { (Waaseth } \\
\text { et al., } \\
\text { 2019), } \\
\text { Norwegia }\end{array}$ & $\begin{array}{l}\text { Qualitative } \\
\text { method with } \\
\text { semi- } \\
\text { structured } \\
\text { interviews }\end{array}$ & $\begin{array}{l}\text { Seven informants } \\
\text { ( } 2 \text { doctors, } 4 \\
\text { nurses, and } 1 \\
\text { pharmacist) }\end{array}$ & $\begin{array}{l}\text { Unable to } \\
\text { understand } \\
\text { electronic } \\
\text { reporting } \\
\text { systems, lack of } \\
\text { reporting time, } \\
\text { poor safety } \\
\text { culture, and } \\
\text { lack of } \\
\text { management } \\
\text { support }\end{array}$ \\
\hline $\begin{array}{l}\text { Patient Safety in } \\
\text { Primary Care: } \\
\text { Incident Reporting } \\
\text { and significant event } \\
\text { Reviews in British } \\
\text { General Practice }\end{array}$ & $\begin{array}{l}\text { Rea \& } \\
\text { Griffiths, } \\
\text { 2016), UK }\end{array}$ & $\begin{array}{l}\text { Qualitative } \\
\text { method with } \\
\text { semi- } \\
\text { structured } \\
\text { interviews }\end{array}$ & $\begin{array}{l}9 \text { general } \\
\text { practitioners }\end{array}$ & $\begin{array}{l}\text { Lack of reporting } \\
\text { time, inadequate } \\
\text { understanding of } \\
\text { what and who to } \\
\text { report, shame } \\
\text { and fear, and } \\
\text { lack of feedback }\end{array}$ \\
\hline $\begin{array}{l}\text { Practice, Perceived } \\
\text { Barriers and } \\
\text { motivating } \\
\text { Factors to Medical- } \\
\text { Incident Reporting: } \\
\text { A } \\
\text { Cross-section } \\
\text { Survey of Health } \\
\text { Care } \\
\text { Providers at } \\
\text { Mbarara regional } \\
\text { referral } \\
\text { Hospital, } \\
\text { Southwestern } \\
\text { Uganda }\end{array}$ & $\begin{array}{l}\text { (Naome et } \\
\text { al., 2020), } \\
\text { Uganda }\end{array}$ & $\begin{array}{l}\text { Cross- } \\
\text { sectional } \\
\text { design with } \\
\text { questionnaire }\end{array}$ & $\begin{array}{l}158 \text { healthcare } \\
\text { workers }\end{array}$ & $\begin{array}{l}\text { Lack of } \\
\text { knowledge } \\
(52.5 \%), \\
\text { absence of } \\
\text { incident } \\
\text { management } \\
\text { team at the } \\
\text { hospital (53.8\%), } \\
\text { failure to } \\
\text { maintain } \\
\text { confidentiality of } \\
\text { reports (58.9\%), } \\
\text { lack of support } \\
\text { from } \\
\text { management } \\
\text { (43.0\%), blaming } \\
\text { culture (40.5\%), } \\
\text { and } \\
\text { administrative } \\
\text { penalties } \\
\text { (65.2\%). }\end{array}$ \\
\hline
\end{tabular}




\begin{tabular}{l}
\hline Incidents Reporting: \\
Barriers and \\
Strategies to \\
Promote Safety \\
Culture
\end{tabular}

$\begin{array}{ll}\text { (Varallo et } & \text { Group } \\ \text { al., 2018), } & \text { conversation } \\ \text { Brazil } & \end{array}$

67 people

Lack of

consisting of accountability

nutritionists, for reporting

physiotherapists, culture psychologists, pharmacists, therapists, doctors, and nurses

\begin{tabular}{|c|c|c|c|c|}
\hline $\begin{array}{l}\text { Medication Errors } \\
\text { among Nurses in } \\
\text { Teaching Hospitals } \\
\text { in the West of Iran: } \\
\text { What We Need to } \\
\text { Know about } \\
\text { Prevalence, Types, } \\
\text { and Barriers to } \\
\text { Reporting }\end{array}$ & $\begin{array}{l}\text { (Fathi et } \\
\text { al., 2017), } \\
\text { Iran }\end{array}$ & $\begin{array}{l}\text { Quantitative } \\
\text { method with } \\
\text { questionnaires }\end{array}$ & $\begin{array}{l}500 \text { nurses from } \\
\text { seven hospitals }\end{array}$ & $\begin{array}{l}\text { High workload } \\
\text { and worry about } \\
\text { consequences } \\
\text { for reporting }\end{array}$ \\
\hline $\begin{array}{l}\text { Perceptions and } \\
\text { Attitudes towards } \\
\text { Medication Error } \\
\text { Reporting in } \\
\text { Primary Care } \\
\text { Clinics: A } \\
\text { Qualitative Study in } \\
\text { Malaysia }\end{array}$ & $\begin{array}{l}\text { (Samsiah et } \\
\text { al., 2016), } \\
\text { Malaysia }\end{array}$ & $\begin{array}{l}\text { Qualitative } \\
\text { method with } \\
\text { in-depth } \\
\text { interviews }\end{array}$ & $\begin{array}{l}31 \text { healthcare } \\
\text { workers }\end{array}$ & $\begin{array}{l}\text { Overlapping } \\
\text { reporting } \\
\text { systems, high } \\
\text { workload, and } \\
\text { lack of } \\
\text { information about } \\
\text { how to report }\end{array}$ \\
\hline $\begin{array}{l}\text { Barriers to Patient } \\
\text { Safety Incident } \\
\text { Reporting by } \\
\text { Brazilian Health }\end{array}$ & $\begin{array}{l}\text { (De Fatima } \\
\text { et al., 2019), } \\
\text { Brazil }\end{array}$ & $\begin{array}{l}\text { Integrative } \\
\text { review }\end{array}$ & $\begin{array}{l}8 \text { journal articles } \\
\text { using a sample } \\
\text { of nurses }\end{array}$ & $\begin{array}{l}\text { Fear }(62.5 \%), \\
\text { overwork } \\
(25.2 \%), \\
\text { forgetting to } \\
\text { report }(22.6 \%) \text {, } \\
\text { embarrassment } \\
(27 \%) \text {, lack of } \\
\text { knowledge } \\
(37.5 \%) \text {, and lack } \\
\text { of responsibility } \\
(50 \%)\end{array}$ \\
\hline $\begin{array}{l}\text { Exploring } \\
\text { Facilitators and } \\
\text { Barriers to } \\
\text { Medication Error } \\
\text { Reporting among } \\
\text { healthcare } \\
\text { Professionals in } \\
\text { Qatar Using the } \\
\text { theoretical } \\
\text { Domains framework: } \\
\text { A Mixed-Methods } \\
\text { Approach }\end{array}$ & $\begin{array}{l}\text { (Stewart et } \\
\text { al., 2018), } \\
\text { Qatar }\end{array}$ & $\begin{array}{l}\text { Sequential } \\
\text { explanatory } \\
\text { mixed } \\
\text { methods with } \\
\text { questionnaires } \\
\text { and FGD }\end{array}$ & $\begin{array}{l}1.604 \\
\text { questionnaire } \\
\text { respondents } \\
(67.9 \% \text { nurses, } \\
13.3 \% \text { doctors, } \\
12.9 \% \\
\text { pharmacists) dan } \\
44 \text { FGD } \\
\text { participants }\end{array}$ & $\begin{array}{l}\text { Concern about } \\
\text { work relationship } \\
\text { and } \\
\text { confidentiality of } \\
\text { reports }\end{array}$ \\
\hline $\begin{array}{l}\text { Improving Incident } \\
\text { Reporting mong } \\
\text { Physician Trainees }\end{array}$ & $\begin{array}{l}\text { (M. } \\
\text { Christopher, } \\
\text { 2016), } \\
\text { Amerika } \\
\text { Serikat }\end{array}$ & $\begin{array}{l}\text { Experimental } \\
\text { study }\end{array}$ & $\begin{array}{l}73 \text { resident } \\
\text { doctors }\end{array}$ & $\begin{array}{l}\text { Lack of } \\
\text { understanding } \\
\text { about the } \\
\text { reporting } \\
\text { system } \\
(72.6 \%) \text {, what }\end{array}$ \\
\hline
\end{tabular}


to report

$(56.2 \%)$, and insufficient time to report

$(42.5 \%)$

Practical and
Cultural Barriers to
Reporting
Incidents Among
Health Workers in
Indonesian
Public Hospitals

(Dhamanti, Mixed

et al., 2020), method with Indonesia

convergent

parallel

design

1,121 health
personnel as
respondents
and 27
hospital
managerial
staff as
informants

Lack of understanding of the reporting system, lack of feedback, fear and complicated reporting system
The literature review comes up with four reasons on why the PSI reporting was not smoothly run.

\section{Shaming and Blaming Culture}

Shaming and blaming culture may worsen PSI reporting culture (Naome et al., 2020). A positive culture is necessary to build individual's awareness of reporting incidents (Samsiah et al., 2016).

Culturally, HCWs tend to avoid conflicts with others, i.e., friends and superiors (Dhamanti, et al., 2020), and thus they do not conduct any reporting habits. Naome et al. (2020) figured out of 158 respondents, $110(69.6 \%)$ favored a work environment without blaming and shaming culture to encourage compliance with incidence reporting.

Further, Christopher (2016) asserted that interactive incidence reporting training would be very important to promote patient safety culture. To compensate this idea, Dhamanti et al. (2020) stated that effective communication within an organization could overcome cultural barriers.

Organization with high incidence reporting rates already have a good perception of patient safety culture (M. Christopher, 2016).All leaders, HCWs, and other staff must be proactive in promoting and implementing a reporting culture (Cheema et al., 2017).

\section{Lack of time}

The high number of patients sometimes does not align with the number of nurses available. The same issue also happened at several hospitals in the provinces of Iran, Taiwan, and Germany (Fathi et al., 2017). Samsiah et al. (2016) demonstrated HCWs mostly spent their time for caring for patients and did not prioritize reporting role.

Another study conducted by Waaseth et al. (2019) mentioned HCWs were too busy during shifts and thus having no time to report incidents. Although the management allows them to report incidents on the next day, most of them forgot to report the incidents. Therefore, strategies should be implemented to reduce their workload (Fathi et al., 2017). A simple and accessible reporting system both manual and web-based could trigger staff motivation to report incidents (Rea and Griffiths., 2016; Waaseth et al., 2019).

\section{Lack of knowledge}

Another barrier is disability to define and report the incidence chronology. Research in Malaysia demonstrated HCWs had no idea to report incidents (Samsiah et al., 2016). In the UK, only $45 \%$ of pharmacists reported adverse drug reactions (ADR). They perceived only serious incidents should be reported (Cheema et al., 2017). However, any medical errors mainly become common incidents that occur (M. Christopher, 2016).

Many countries have developed incident reporting tools nationwide. However, it might be that as Samsiah et al. (2016) stated, reporting systems could be overlapping and become another barrier. For example, the Malaysia Ministry of Health $(\mathrm{MOH})$ introduced a system called the Medication Error Reporting System 
(MERS) in August 2009. Apart from MERS, there are also IQ, QAP, and PF statistics which confuse most of the HCWs.

In Brazil, since 2013, hospitals have been called on to report incidents as the country wants to bolster patient safety (De Fatima et al., 2019). The University Hospital of North Norway used a webbased reporting management system, but not all staff could access to the system which was not integrated to all units.

Training on incidence reporting is required for all staff to emphasize on what have been taught (Waaseth et al., 2019). Reporting should be easy, not bureaucratic, and free of hierarchy (De Fatima et al., 2019). Sustainable training will keep HCWs to get used to incidence reporting (Samsiah et al., 2016).

In Uganda, $55.7 \%$ of respondents should go on training on incidence identification, and $60.1 \%$ needed written guidelines. Educative media about how to report incidence are prominent for the staff (Naome et al., 2020). For example, hospital management can provide an incident reporting flowchart to give more simple incidence reporting procedures (Samsiah et al., 2016).

Several hospitals in Indonesia routinely hold training on safety and incidence reporting programs. However, they did not expel any optimum results. Socialization on the system has to reach all units at the hospital (Dhamanti, et al., 2020).

\section{Lack of support}

Leader commitment to PSI reporting is another factor that contributes to the success of the system. Waaseth et al. (2019) mentioned that doctors and nurses perceived poor commitment to incidence reporting existed in the managerial level.

The absence of rewards and appreciation is another reason on why staff is unaware of incidence reporting. As a result, staff does not make any positive change (De Fatima et al., 2019).

Dhamanti et al. (2020) indicated 52\% of respondents received no feedback from their leaders. Meanwhile, according to Samsiah et al. (2016), feedback across organization's units positively cultivates staff's interests in continuous incidence reporting. Moreover, it will increase motivation and compliance with incidence reporting (Naome et al., 2020). Lack of responsibility from HCWs is the other barrier in PSI reporting. To achieve goals in incidence reporting, leaders must address staff with educational interventions where knowledge is transferred actively (Varallo et al., 2018).

\section{Conclusion}

PSI reporting is essential for patient safety programs to avoid recurrent mistakes. The barriers that occur are the existence of shaming and blaming culture, lack of time to report, lack of knowledge of the reporting system, and lack of support from the management.

Stakeholders and policy makers require incident reports to reduce the impacts of PSI. Further research needs to be done using more samples in various countries to further collect more data on incidence reporting culture.

\section{Abbreviations}

HCWs: healthcare workers; PSI: patient safety incidents.

\section{Declarations}

\section{Conflict of Interests}

The authors declare that there is no conflict of interests that might have affected the performance.

\section{Availability of Data and Materials}

Data and materials are available in an open data repository (Institutional Repository Data).

\section{Authors' Contribution}

All of the authors conceptualized the study. DAN wrote the manuscript and AW reviewed the manuscript. Author and coauthor discussed the issues together.

\section{Acknowledgment}

We would like to thank the Faculty of Public Health, Universitas Airlangga and all contributors for supporting our research. 


\section{References}

Cheema, E., Haseeb, A., Khan, T. M., Sutcliffe, P., and Singer, D. R. (2017). Barriers to reporting of adverse drugs reactions: A cross sectional study among community pharmacists in United Kingdom. Pharmacy Practice, 15(3), $1-7$. https://doi.org/10.18549/PharmPract. 2017.03.931

De Fatima, T. A. M., De Carvalho, D. S., and De Albuquerque, G. S. C. (2019). Barriers to patient safety incident reporting by brazilian health professionals: An integrative review. Ciencia e Saude Coletiva, 24(8), 2895-2908.

https://doi.org/10.1590/141381232018248.23912017

Dhamanti, et al. (2020). Practical and cultural barriers to reporting incidents among health workers in Indonesian public hospitals. Journal of Multidisciplinary Healthcare, 13, 351359.

https://doi.org/10.2147/JMDH.S24012 4

Fathi, A., Hajizadeh, M., Moradi, K., Zandian, H., Dezhkameh, M., Kazemzadeh, S., and Rezaei, S. (2017). Medication errors among nurses in teaching hospitals in the west of Iran: what we need to know about prevalence, types, and barriers to reporting. Epidemiology and Health, 39(June), e2017022. https://doi.org/10.4178/epih.e201702 2

M. Christopher, A. M. L. S. (2016). Improving Incident Reporting Among Physician Trainees. Physiology \& Behavior, 176(1), 100-106. https://doi.org/10.1097/PTS.0000000 000000325.Improving

Naome, T., James, M., Christine, A., and Mugisha, T. I. (2020). Practice, perceived barriers and motivating factors to medical-incident reporting: $A$ cross-section survey of health care providers at Mbarara regional referral hospital, southwestern Uganda. BMC Health Services Research, 20(1), 1-9. https://doi.org/10.1186/s12913-02005155-z
Rea, D., \& Griffiths, S. (2016). Patient safety in primary care: incident reporting and significant event reviews in British general practice. Health and Social Care in the Community, 24(4), 411-419.

https://doi.org/10.1111/hsc. 12221

Samsiah, A., Othman, N., Jamshed, S., and Hassali, M. A. (2016). Perceptions and attitudes towards medication error reporting in primary care clinics: A qualitative study in Malaysia. PLoS ONE, 11(12), 1-19. https://doi.org/10.1371/journal.pone.0 166114

Stewart, D., Thomas, B., MacLure, K., Wilbur, K., Wilby, K., Pallivalapila, A., Dijkstra, A., Ryan, C., El Kassem, W., Awaisu, A., McLay, J. S., Singh, R., and Hail, M. Al. (2018). Exploring facilitators and barriers to medication error reporting among healthcare professionals in Qatar using the theoretical domains framework: A mixed-methods approach. PLoS ONE, 13(10), 1-19. https://doi.org/10.1371/journal.pone.0 204987

Varallo, F. R., Passos, A. C., Nadai, T. R. de, and Mastroianni, P. de C. (2018). Incidents reporting: barriers and strategies to promote safety culture. Revista Da Escola de Enfermagem Da

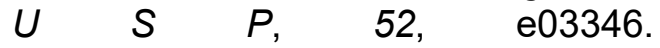
https://doi.org/10.1590/S1980220X2017026403346

Waaseth, M., Ademi, A., Fredheim, M., Antonsen, M. A., Brox, N. M. B., and Lehnbom, E. C. (2019). Medication Errors and Safety Culture in a Norwegian Hospital. Studies in Health Technology and Informatics, 265, 107-112.

https://doi.org/10.3233/SHTI190147

World Health Organization. (2020). Patient Safety Incident Reporting and Learning Systems. 